\title{
Fast and Not Furious
}

\author{
Luiz Lopes Lemos Junior ${ }^{1}$, Fábio Evangelista Santana ${ }^{2}$, Fernando Antonio Forcellini ${ }^{3}$, \\ Luiz Fernando Vaseak Machado ${ }^{4}$, and João Paulo Castilho ${ }^{5}$ \\ 1,4,5 IFSC, Rua Euclides Hack 1603, 89820-000, Xanxerê, SC, Brazil \\ ${ }^{2}$ IFSC, Avenida XV de Novembro 61, Araranguá, 88900-000, SC, Brazil \\ ${ }^{3}$ EMC-UFSC, Caixa Postal 476, Campus Universitário, 88040-900 - Florianópolis, SC, Brazil \\ luiz.lemos@ifsc.edu.br, fsantana@gmx.de, forcellini@emc.ufsc.br, \\ \{nandinhu_tb, joaocastilhoo\} @hotmail.com
}

\begin{abstract}
Two projects sequentially made planed and constructed of a wheelchair-low-cost and a car to run at the academic Gravity Racing Championship. The intention of them is provide to the Brazilian market a more durable and cheaper standard manual wheelchair and a racing car to access for a wheelchair and its driver. They were designed in CAD program for product engineering (modeling in 3 axis). The mechanical elements of movements were bought and retrofitted to the innovative structures. As the racing car was a 4 wheels model, the steering was inspired in the same used in kart models and the breaks and wheels were cycling components. The loading and unloading system was made by the driver without assistance of anyone (a ramp helps the person to load the wheelchair in the car and the person set the ramp up for safety). The car was not equipped with any propulsion equipment because the championship rules admit only the influence of gravity.
\end{abstract}

Keywords: Wheelchair, Mechanical Construction, Racing Car for Wheelchair, Vehicle for Wheelchair, Mechanical Manufacturing, Paraplegia.

\section{Introduction}

The project shows the construction of a standard manual wheelchair and the construction of a racing car to access for a wheelchair and its driver, which original idea started from Fábio Evangelista Santana. Two groups worked sequentially: the first group intended to provide the Brazilian market with a more durable and cheaper standard manual wheelchair; the other, designed and built a car to support the wheelchair-low-cost to participate of a Gravity Racing Championship.

The wheelchair metallic structure prototype was designed in CAD program for product engineering (modeling in 3 axis) obeying the standard dimensions of the most popular wheelchair model of reference of ABNT NBR 9050 (the Brazilian Organization for Standardization). To achieve the main objective, the wheelchair should have a few custom parts, focusing on the design and construction of the 
structure to receive these parts and how assembling the set easily and fast. The mechanical elements of movements, the seat and the backrest were bought and retrofitted to the innovative structure.

Using the three-dimensional model of the wheelchair developed before, the racing car for the academic championship "Gravity Racing", which occurs annually in Araranguá, Brazil, was designed in the CAD program which run dimensional and stress-strain analysis. As the vehicle was a 4 wheels model, the steering was inspired in the same used in kart models and the breaks and wheels were cycling components. There is a locking system to couple the wheelchair in the car. It works locking at 6 positions simultaneously: the two smaller wheels, the two larger (rear) and the two armrests. The loading and unloading system is made by the driver without assistance of anyone (a ramp helps the person to load the wheelchair in the car and the person set the ramp up for safety). The car was not equipped with any propulsion equipment because the championship rules admit only the influence of gravity.

So much for one as for the other project, the roll cage was built with AISI 1010 carbon steel tubes of $22 \mathrm{~mm}$ outside diameter and $3 \mathrm{~mm}$ wall thickness. The most of the fixed parts were welded by MAG process to offer better finish or screwed into internal threads machined in the structure in order to provide greater security to the user avoiding protruding parts.

The wheelchair prototype would be used in the IFSC, Campus Xanxerê, in case of emergency and the racing car would be adapted for donation as a vehicle of transportation to a wheelchair user in need.

\section{Theoretical Framework}

\subsection{Wheelchair-low-cost}

According to the Instituto Brasileiro de Geografia e Estatística (IBGE), 2002, there are around $2.5 \%$ of the Brazilian population has mobility disabilities, which are temporary or permanent. So, the choice of both projects for the final course project is related to the promotion of accessibility, which is a subject of great importance to the reality of the community.

Despite being a standard for accessibility, ABNT NBR 9050 is free and easily accessible option to search in the Internet for students in undergraduate research technical standard. Another advantage is that it contains the basic dimensions for the construction of the wheelchairs as the ergonomic aspects of the Brazilian population, as shown in Figure 1. 


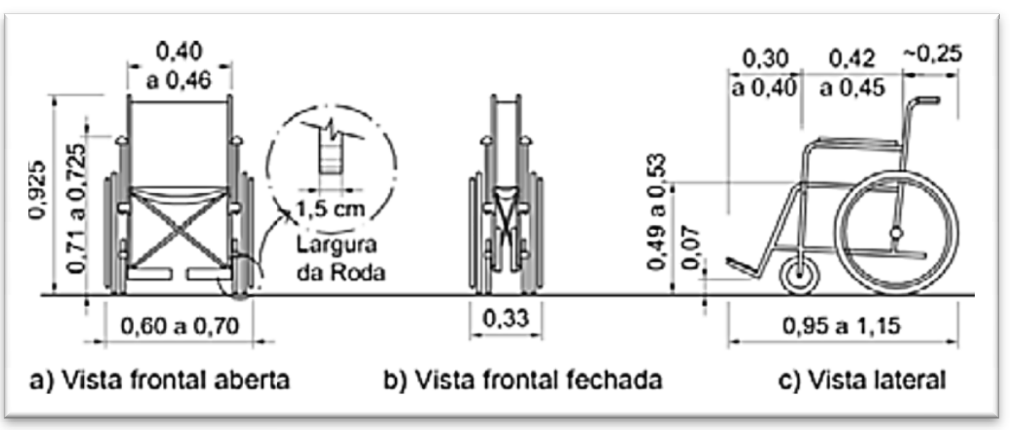

Fig. 1. Wheelchair standard dimensions NBR 9050, 2004

CAD Software. Using these known dimensions, the firsts prototypes in computer began to be created in 3D CAD using SolidWorks ${ }^{\circledR}$ software. This program was chosen because it is currently popular among mechanical manufacturing enterprises for its easy learning because its multilingual interface is highly intuitive (it includes Portuguese language, as in Figure 2). In addition, SolidWorks ${ }^{\circledR}$ contains a huge library of parts available for free by users throughout Internet access in file format of the program and the software is also able to import other formats too. The software is not free, but the IFSC own licenses to use it in professional courses.

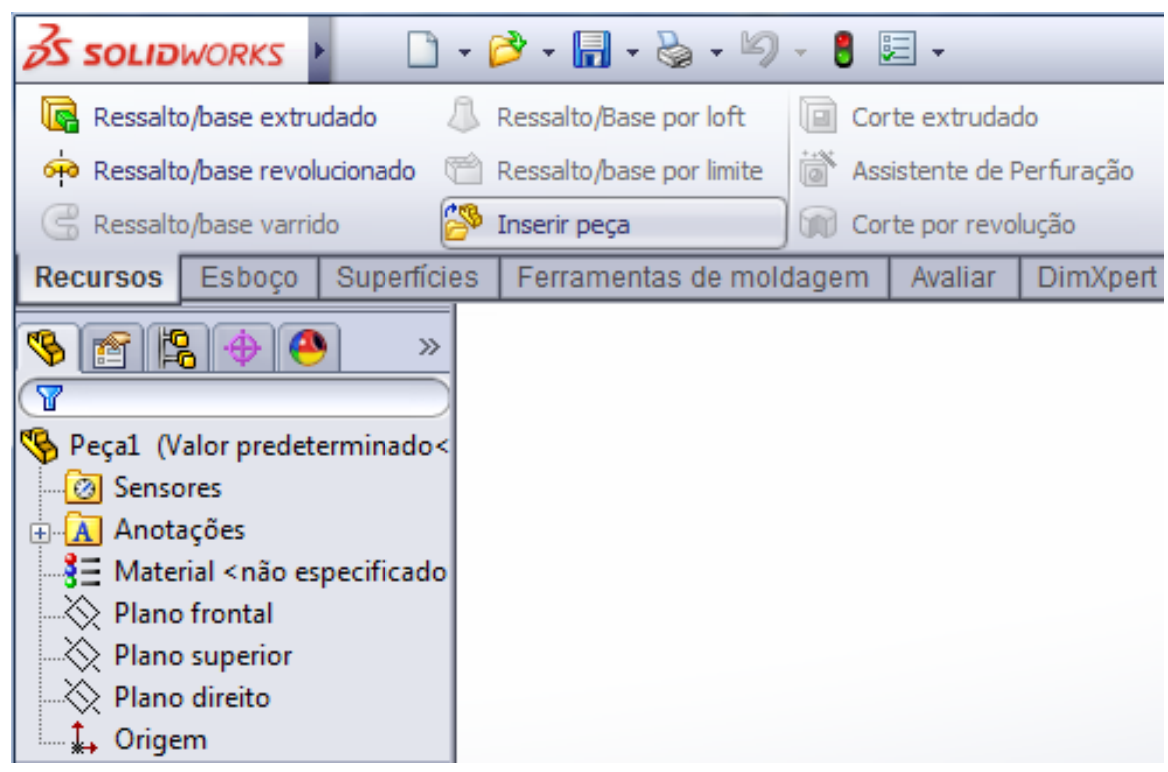

Fig. 2. Print screen of SolidWorks ${ }^{\circledR}$ interface: ease icons and translated to Portuguese Property of the authors 
Rear wheel (large wheel or wheel of traction) is the largest wheel chair positioned generally behind, being in adult chairs in general rim 24 inches in diameter. Two kinds of wheels are more used the pneumatic and the solid tires. The pneumatic wheels are composed of a camera and a tire air. The rolling resistance and comfort these tires depend largely on the pressure they are (ability to absorb shocks arising from irregularities of the floor). On the other hand, the solid tires are more durable, but used for short ways. Solid tires are recommended for use by emergency wheelchairs for shops and hospitals and always indoor. They are less comfortable then the pneumatic ones.

The casters are usually placed at the front of a wheelchair and shall consist of the following components: wheel, fork, stem and rod bearings. As the rear wheels casters may have pneumatic or solid wheels too. The casters may vary between 3 and 8 inches. (RODRIGUES, 1994).

The back rest and cushion are very import for many people who use wheelchair spend more than 20 hours per day in the sitting and lying positions, thereby causing various problems in the muscles and the gluteal region, such as skin necrosis and ulcer formation, also causing serious problems of posture (GILSDORF, 1990). The selection of the appropriate seat padding and should take into account the following factors (COOPER, 1998), stability of support for arms, pressure distribution, maintenance of posture to prevent deformities, weight and ease of cleaning and durability.

The frame is part of the wheelchair that supports the weight of the user, the own weight and which are linked wheels, casters, the footrests and armrests, seat and back (RODRIGUES, 1994). Galvanized steel is a material with low cost, good weldability and high mechanical strength, and has already contains a coating of corrosion requires no treatment or another type of process for its greater durability. According to ABNT NBR 5590 (ASTM A-53), galvanized tubes with chemical composition and mechanical properties in B grade, with $0.30 \%$ of carbon and maximum $1.20 \%$ of manganese, has yield strength of $240 \mathrm{MPa}$ minimum and compressive strength of $415 \mathrm{MPa}$, and deformation greater than or equal to $23 \%$.

\subsection{Racing Car}

Annually, there was a racing car for the academic championship "Gravity Racing", which occurs in Araranguá, Brazil. After the challenge, the cars became in waste. By the accumulation of junk on campus, Professor Fábio Evangelista Santana proposed a way to reuse the cars, adapting a structure a wheelchair. The campus would keep few cars on and wheelchairs would be manufactured each challenge.

\subsection{Sustainability}

In the prototype manufacturing processes were created solid waste metals which IFSC gave the appropriate destination as expected by national laws. Disposal of waste was done according to the ABNT NBR 10.004:2004. Residues class II-A is not inert, such as residues of class II-B is. These two types of waste were produced and them can be recycled or disposed in standard landfills or landfills for recyclable waste. 


\section{Methodology}

\subsection{Wheelchair-low-cost}

After completion of the design phase in $\mathrm{CAD}$, it was prepared a list of materials to be machined and another for purchasing parts. It was difficult to buy parts to a compatible price for the project, because parts for wheelchairs are rarely marketed in the country. From the same supplier were purchased: 24' rear wheels and front casters. Of cycling shops were bought push handles. The back rest, the cushion, and the arm rest, were built for an expert of restorations of sofas. The frame and the rest of the structure as the foot plate were machined in the campus. The wheelchair type chosen involved a low-grade technological complexity in its manufacture, for the rigid frame (unibody) for internal use and the material used to machine: AISI 1010 carbon steel tubes of $22 \mathrm{~mm}$ outside diameter and $3 \mathrm{~mm}$ wall thickness.

A good option to weld a AISI 1010 carbon steel tube is the MAG process because it offers better finish, low chances of weld bead defects, and increased productivity compared to other methods.

Manufacturing Processes. For the wheelchair, were used these manufacturing processes (see Table 1):

Table 1. Manufacturing process for wheelchair-low-cost (property of the authors)

\begin{tabular}{|c|c|c|}
\hline $\begin{array}{l}\text { Manufacturing } \\
\text { process }\end{array}$ & Tool & Function \\
\hline Cutting & Bandsaw & $\begin{array}{l}\text { To cut round tubes and sheets for } \\
\text { assembly the structure }\end{array}$ \\
\hline Bending & Bending machine & $\begin{array}{l}\text { To bend the tubes to create the } \\
\text { frame; }\end{array}$ \\
\hline Milling & Milling machine & To mill the tubes \\
\hline Turning & Metalworking lathes & To machine the tips axle \\
\hline Drilling & Electric drill & $\begin{array}{l}\text { To drill for screws bodies pass } \\
\text { through }\end{array}$ \\
\hline Welding & MIG/MAG equipment & $\begin{array}{l}\text { To weld the tubes and the plates of } \\
\text { the structure }\end{array}$ \\
\hline $\begin{array}{l}\text { Surface } \\
\text { finishing }\end{array}$ & Sander and spray painting & $\begin{array}{l}\text { To finish to improve the look of it } \\
\text { and decrease the oxidation of metals } \\
\text { in contact with the atmosphere }\end{array}$ \\
\hline Assembling & --- & $\begin{array}{l}\text { To assembly the parts of the } \\
\text { structure with the other steering } \\
\text { components and moving parts }\end{array}$ \\
\hline
\end{tabular}


To develop the prototype, mechanical manufacturing processes, such as it was planned:

- Machining: the frame were machined in a conventional mechanical around the axis of the rear wheels, with SAE 1020 steel, for fixing the bearings, then cut manually with M12 thread screw. Conventional milling machine was used to machine the tubes, thus preparing the welding and improved design.

- Bend: to bend the tubes was used an automatic hydraulic bending machine for tube. The folds have been made for a specific tool with the diameter of the tube used. This tool was produced in SAE1045 steel and the heat treatment temperature and tempering for the best hit of bend angles. The smooth operation of the tool and the machine depend on the tolerance being obeyed $(+0.05 \mathrm{~mm}$ to 0$)$ as calculated to avoid manufacturing defects, for example, stretch and rupture. The machinery and tooling was donated by the local company CM Cunha Machines LTDA.

- Cutting: to cut the tubes to the structural steel and details were executed using electric hand saw, sander and poly cutting machine with straight cuts and 45 degrees cuts.

- Welding: to weld, the type chosen for the mounting of the chair was MAG welding: using $\mathrm{CO}^{2}$ active gas and $0.8 \mathrm{~mm}$ steel wire.

- Assembling: the use of brackets is mounted all the parts of the chair and soldered one by one to make them in symmetry. With grinders with finishing disc was removed the exceeded weld bead. Imperfections that remained were filled with plastic mass, was removed after the excess dough with sandpaper and apply the background paint for metal protection improving the painting. The rear and front wheels were purchased ready-made and only assembled in the structure.

\subsection{Racing Car}

The first idea was not possible to put in action because the car were so unstable (see Fig. 3). Then, the solution was design an independent car to carry the wheelchair on.

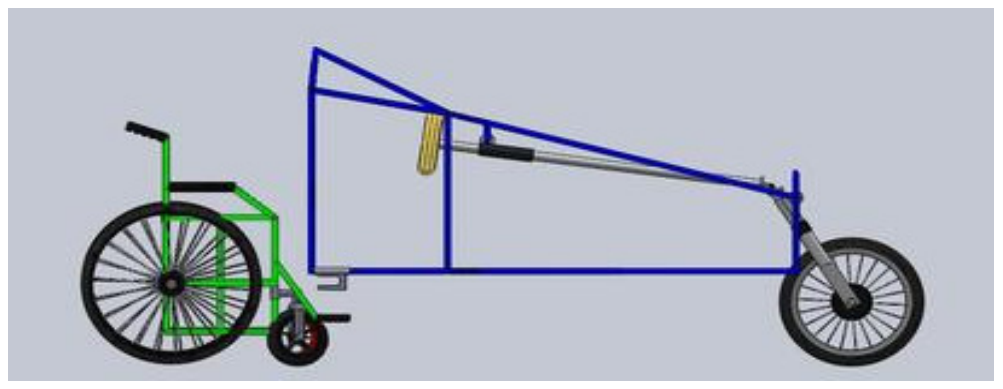

Fig. 3. First conceptual prototype (property of the authors)

Some models with three wheels were tested for the racing car nevertheless the results of analysis showed instability running in curves. The four wheels model was the best solution, as shown in Figure 4. 


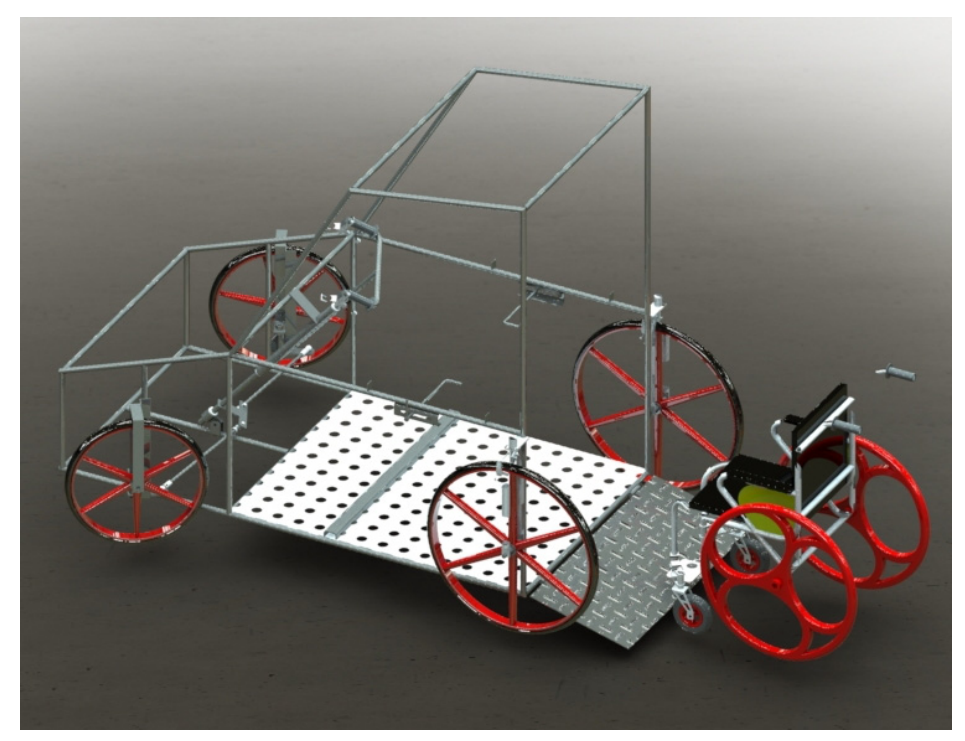

Fig. 4. Racing car prototype (property of the authors)

The method to create the prototype was similar the method used for the wheelchair-low-price. The three-dimensional assembly model of the wheelchair developed before, was used to design in the CAD program SolidWorks ${ }^{\circledR}$ which run dimensional and stress-strain analysis.

The materials used to machined were, the most part, bought when the first project was made.

As the vehicle was a four wheels model, the steering was inspired in the same used in kart models and the breaks and wheels were cycling components. There is a locking system to couple the wheelchair in the car. It works locking at 6 positions simultaneously: the two smaller wheels, the two larger (rear) and the two armrests. The loading and unloading system is made by the driver without assistance of anyone (a ramp helps the person to load the wheelchair in the car and the person set the ramp up for safety).

The car was not equipped with any propulsion equipment because the championship rules admit only the influence of gravity.

Manufacturing Processes. For the racing car, were used these manufacturing processes (see Table 2): 
Table 2. Manufacturing process for racing car (property of the authors)

\begin{tabular}{|c|c|c|}
\hline $\begin{array}{l}\text { Manufacturing } \\
\text { process }\end{array}$ & Tool & Function \\
\hline Cutting & Bandsaw & $\begin{array}{l}\text { To cut round tubes and sheets for } \\
\text { assembly the structure }\end{array}$ \\
\hline Turning & Metalworking lathes & To machine the tips axle \\
\hline Drilling & Electric drill & To drill of coupling parts to the chair \\
\hline Welding & MIG/MAG equipment & $\begin{array}{l}\text { To weld the tubes and the plates of the } \\
\text { structure }\end{array}$ \\
\hline $\begin{array}{l}\text { Surface } \\
\text { finishing }\end{array}$ & Sander and spray painting & $\begin{array}{l}\text { To finish to improve the look of it and } \\
\text { decrease the oxidation of metals in } \\
\text { contact with the atmosphere }\end{array}$ \\
\hline Assembling & --- & $\begin{array}{l}\text { To assembly the parts of the structure } \\
\text { with the other steering components and } \\
\text { moving parts }\end{array}$ \\
\hline
\end{tabular}

So much for one as for the other project, the roll cage was built with AISI 1010 carbon steel tubes of $22 \mathrm{~mm}$ outside diameter and $3 \mathrm{~mm}$ wall thickness and the mechanical processes were the same also: welded by MAG process to offer better finish or screwed into internal threads machined in the structure in order to provide greater security to the user avoiding protruding parts.

\section{$4 \quad$ Results}

Both projects were planned and executed within the period of one year each: the hours of study in the discipline of Design in the Professional Course in Mechanical Manufacture. The areas of education, research and project of extension of the Federal Institute of Santa Catarina (IFSC) were involved.

\subsection{Wheelchair-low-cost}

Upon three months to completion of the development and assembly of the wheelchair-low-cost project, there were difficulties for the purchase the specific parts of the wheelchair and to project the machinery for machining bends in tube materials. However, it was possible to complete the project within the stipulated time. The project had its chief merit in the dissemination of know-how to manufacture an assistive technology for the IFSC. The entire project was systematically writing and filed at the campus library and made available for the next groups begin their studies from this.

The course proved to be economically viable. The wheelchair designed were compared with the cheapest standard manual wheelchair for sale: the designed wheelchair got selling price of $\mathrm{R} \$ 246.55$ (US\$103.72 ${ }^{1}$ ), and the industrial

1 Date of exchange rates: Jan 5th, 2014. 
wheelchair (without shipping) cost R \$ 261.19 (US\$109.89), the designed one had up to $200 \mathrm{~kg}$ of capacity weight and the industrial wheelchair had up to $80 \mathrm{~kg}$. Considering a profit margin of 5 percent, the project will be around $\mathrm{R} \$ 259.00$ (US\$109.00) of sale price.

\subsection{Racing Car}

Initially, the group considered to design of the racing car a very low complexity project; however, the innovative character was challenging at last months. That is because innovation proved a positive difference but an obstacle in some respects, because there is no reference for discussion. The model had to find solutions outside the area of Assistive Technology and inspiration in other technological areas to solve problems. The major problems to be overcome were the steering system and closing the ramp after loading the driver. The cost of the racing car prototype materials was $\mathrm{R} \$ 428.00$ (US $\$ 180.07^{2}$ ).

The car is capable of carrying $160 \mathrm{~kg}$ (352.75 pounds) safely. Therefore it was able to carry the wheelchair and the driver by computing simulation results (see Fig. 5).

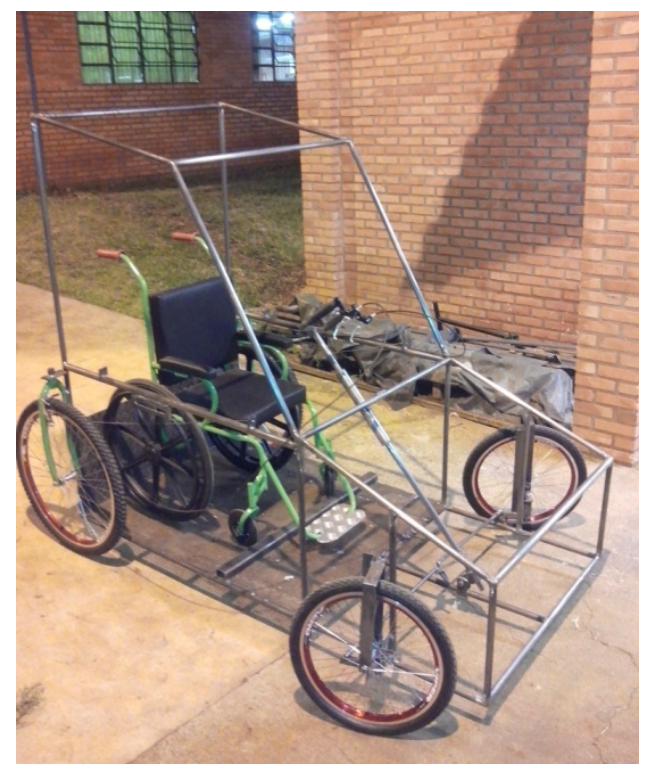

Fig. 5. Racing car with wheelchair-low-cost loaded Photographer: authors

2 Date of exchange rates: Jan 5th, 2014. 


\subsection{Sustainability}

For the environment, we had a huge gain on disposal of scrap generated by projects without proper allocation of use aimed at the simple practice of acquired knowledge or a temporary use of designed objects. The gravity racing cars that had no destination after the competition, from now will be reaped by future groups because the next develop new chairs to compete. Wheelchairs and racing cars can be used by people with disabilities during the intervals of competitions as for leisure as for conventional utility.

\section{Discussions}

The projects aligned the plane of access of the Instituto Federal de Santa Catarina (IFSC) to motivate disabled people to study for the professional qualification of them, highlighting the differences between people with and without disabilities. Then, the social impacts are intangible because some students had their first contact with people with disabilities for the first time. As shown in Figure 6, students visited institutions of support people with disabilities, their homes or received visits from people with disabilities in the IFSC. People with disabilities also had the opportunity to attend the campus and to meet new people and technologies.

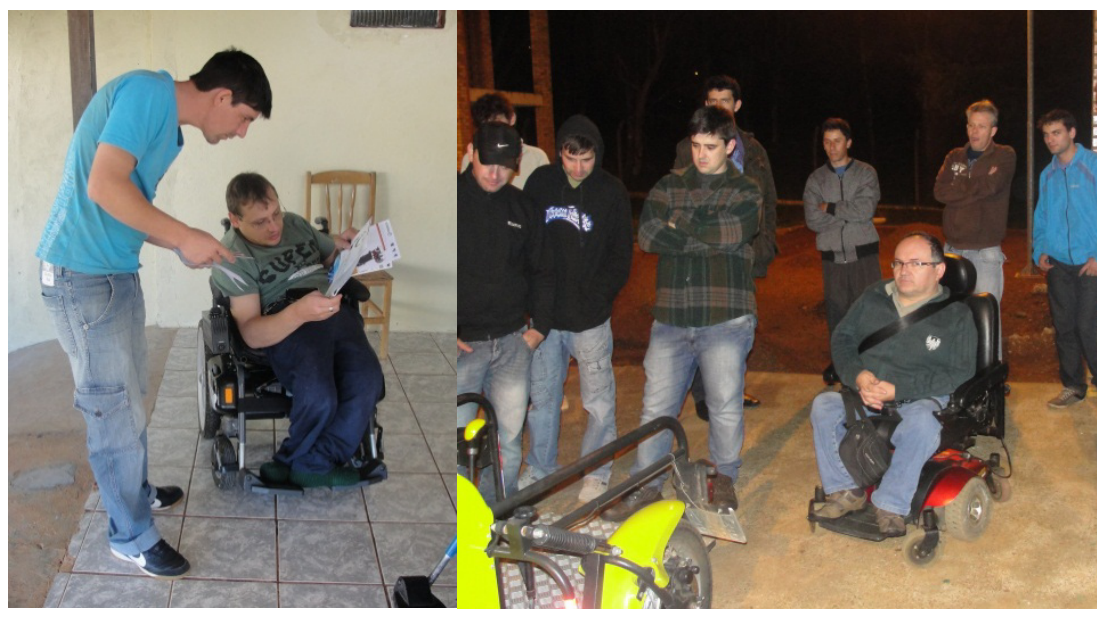

Fig. 6. People who use wheelchair discussing about technologies for disable Photographer: authors

Technologically, the project made room for future projects. It is possible to motorize the wheelchair or the race car, because its structure was designed for this overweight. When these adjustments are completed, both projects can be donated to people who are unable to pay it. 
New projects wheelchair can be made in order to produce customized chairs, because they are much more expensive than conventional. Custom wheelchairs are built for people with non-standard anatomies, such as children and obese people.

\section{References}

1. Associação Brasileira De Normas Técnicas. NBR 9050: Acessibilidade a edificações, mobiliário, espaços e equipamentos urbanos, Rio de Janeiro (2004)

2. ABNT. Associação Brasileira De Normas Técnicas. NBR 10004. Resíduos sólidos Classificação, Rio de Janeiro (2004)

3. Brasil. Coletânea da Legislação sobre os Direitos da Pessoa Portadora de Deficiência. 2. ed. revisada e atualizada, 240 p. SETASS, Campo Grande-MS (2005)

4. Brasil. Constituição Da República. Capítulo III. Da educação, da cultura e do desporto. Seção I. Da educação Art. 205. Art. 206. Art. 208

5. Brasil. IBGE. Censo demográfico (2010)

6. Cooper, R.A.: Wheelchair Selection and Configuration. Demos Medical Publishing, New York (1998)

7. Gilsdorf, P., et al.: Sitting forces and wheelchair mechanics. Journal of Rehabilitation 27(3), 239-246 (1990)

8. Ribeiro, F.L.B.: Introdução ao Método dos Elementos Finitos. COPPE/UFRJ, Rio de Janeiro (2004)

9. Rodrigues, P.B., Silva, A.F.: Cadeiras de rodas manuais-Factores que influenciam a performance de uma cadeira de rodas, Lisboa (1994), http: / /www. inr.pt/ download. php? filename $=29+-+$ Cadeiras + de + rodas + manuai $s \&$ file $=\% 2$ Fuploads $\% 2$ Fdocs $\% 2$ FEdicoes $\% 2 F F o l h e t o s \% 2 F F o l h e t o 029$.rtf (accessed in: December 19, 2013) 